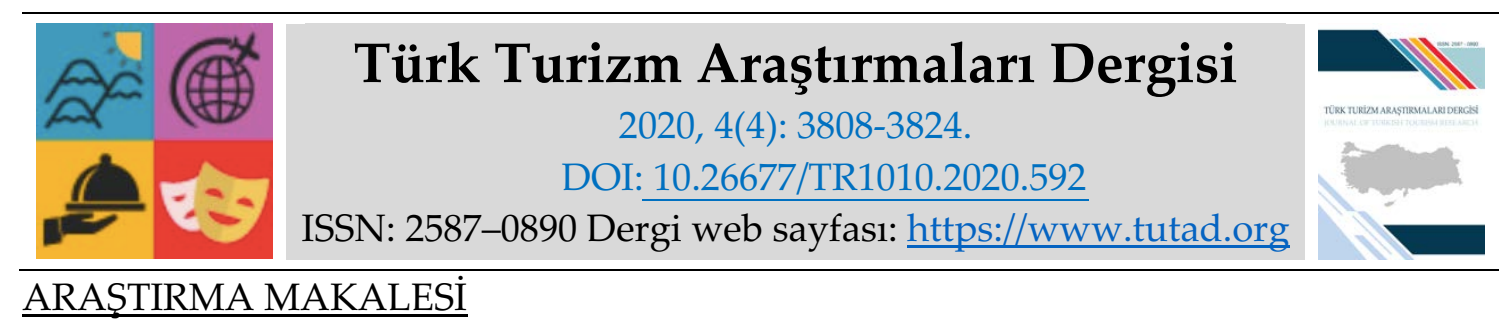

\title{
Otel İşletmeleri Çalışanlarının Algıladıkları Otantik Liderlik Davranışının Psikolojik Sözleşme ve İşten Ayrılma Niyeti Üzerindeki Etkisi: Antalya Örneği
}

Manolya GÜLER, Yüksek Lisans Öğrencisi, İskenderun Teknik Üniversitesi, Sosyal Bilimler Enstitüsü, Hatay, e-posta: manolyaguler@hotmail.com

ORCID: https://orcid.org/0000-0002-3420-4736

Dr. Öğr. Üyesi Hasan CINNIOĞLU, İskenderun Teknik Üniversitesi, Turizm Fakültesi, Hatay, eposta: hasan.cinnioglu@iste.edu.tr

ORCID: https://orcid.org/0000-0001-7826-619X

Öz

$\mathrm{Bu}$ araştırmanın temel amacı otel işletmeleri çalışanlarının yöneticilerinde algıladıkları otantik liderlik davranışının psikolojik sözleşme ve işten ayrılma niyeti düzeylerine etkisini belirlemektir. Araştırmanın evrenini Antalya'da faaliyet gösteren beş yıldızlı otel işletmeleri çalışanları oluşturmaktadır. Araştırmanın amacını gerçekleştirmek için basit tesadüfi örneklem yöntemi ile seçilen 402 otel çalışanından anket tekniği ile veriler elde edilmiştir. Araştırmada çalışanların otantik liderlik ve psikolojik sözleşme algı düzeyinin orta; işten ayrılma niyetlerinin ise düşük seviyede olduğu belirlenmiştir. Aynı zamanda araştırma sonucunda otantik liderliğin psikolojik sözleşme düzeyini pozitif yönde, işten ayrılma niyetini ise negatif yönde etkilediği tespit edilmiştir.

Anahtar Kelimeler: Otantik Liderlik, Psikolojik Sözleşme, İşten Ayrılma Niyeti, Turizm. Makale Gönderme Tarihi: 09.07.2020

Makale Kabul Tarihi: 06.10.2020

\section{Önerilen Atıf:}

Güler, M. ve Cinnioğlu, H. (2020). Otel İşletmeleri Çalışanlarının Algıladıkları Otantik Liderlik Davranışının Psikolojik Sözleşme ve İşten Ayrılma Niyeti Üzerindeki Etkisi: Antalya Örneği, Türk Turizm Araştırmaları Dergisi, 4(4): 3808-3824.

(c) 2020 Türk Turizm Araştırmaları Dergisi. 


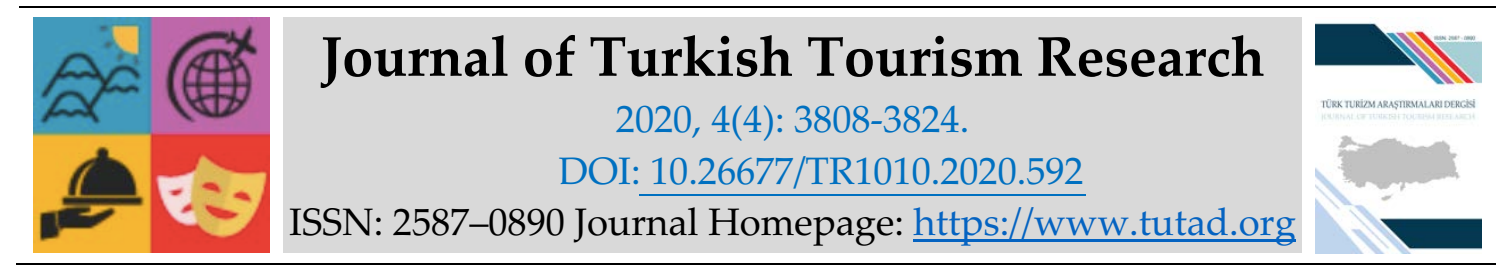

\title{
$\underline{\text { RESEARCH PAPER }}$
}

\section{The Effect of the Authentic Leadership Behavior Perceived by the Employees of Hotel Business on Psychological Contract and the Intention to Leave: Antalya Sample}

Manolya GÜLER, MSc. Student, İskenderun Technical University, Social Sciences Institute, Hatay, e-mail: manolyaguler@hotmail.com

ORCID: https://orcid.org/0000-0002-3420-4736

Assistant Prof. Dr. Hasan CINNIOĞLU, İskenderun Technical University, Faculty of Tourism, Hatay, e-mail: hasan.cinnioglu@iste.edu.tr ORCID: https://orcid.org/0000-0001-7826-619X

\begin{abstract}
The main purpose of this research is to determine the effect of the authentic leadership behavior perceived by the employees of the hotel businesses on their psychological contract and intention to quit. The universe of the research consists of five-star hotel management employees operating in Antalya. In order to realize the purpose of the research, data was obtained from the survey staff from 402 hotel staff selected by simple random sampling method. The level of perception of employees' authentic leadership and psychological contract is medium; it is determined that their intention to leave is low. At the same time, as a result of the research, it has been determined that authentic leadership affects the psychological contract level positively and the intention to quit negatively.
\end{abstract}

Keywords: Authentic Leadership, Psychological Contract, Intention to Leave, Tourism.

Received: 09.07.2020

Accepted: 06.10.2020

\section{Suggested Citation:}

Güler, M. and Cinnioğlu, H. (2020). The Effect of the Authentic Leadership Behavior Perceived by the Employees of Hotel Business on Psychological Contract and the Intention to Leave: Antalya Sample, Journal of Turkish Tourism Research, 4(4): 3808-3824.

(C) 2020 Türk Turizm Araştırmaları Dergisi. 


\section{Gíriş}

İşletmeler hedeflerine ulaşmak için, artan rekabet ortamında ayakta kalmalı ve değişen çevre koşullarına ayak uydurmalıdırlar. İşletmenin gelişmesinde ve rekabet avantajı sağlamasında yöneticilerin yerinin oldukça önemli olduğunu söylemek mümkündür. Hizmet sektöründe yer alan otel işletmelerinde, çalışanların işletmenin hedeflerini gerçekleştirebilmesi için motive edilmesinde liderin sergilediği davranışlar oldukça etkilidir (Akgündüz, 2012:1). Otel işletmeleri, emek yoğun çalışan işletmeler olması nedeniyle, insan kaynağı unsurunun işletme açısından önemli olduğu söylenebilir. Çalışanların, işletmede yaşadığı olumlu veya olumsuzluklar, çalışanın işe karşı olan tutumunu etkilediğini söylemek mümkündür. Ayrıca, örgüt bağlılığı yüksek olan çalışanların, işletmeye daha verimli hizmet verdiği söylenebilir. Otantik liderlik davranışını sergileyen liderler, çalışanlara güven duygusunu benimsetirler ve karar verirken veya sergiledikleri davranışlarda, ahlaki değerlere ve etik kurallara uyarak çalışanların güvenini kazanırlar, böylelikle güven ortamı oluşturamayan işletmelerde, otantik liderlik anlayışı benimseyen yöneticiler sayesinde güven problemi ortadan kalkar (Kılınç ve Akdemir, 2019:794). İ̧̧letme ile çalışanlar arasında yapılan yazılı sözleşmelerin, çalışanı açılamaya yetersiz kalması durumda psikolojik sözleşmeler ortaya çıkmıştır (Mimaroğlu, 2008:48). Psikolojik sözleşmenin ihlal edilmesi durumunda, çalışanların işletmeye karşı duyguları, tutum ve davranışları olumsuz yönde değişir. Çalışanların işletmeye karşı olumsuz duygular beslemesi; verimliliği, performansı ve iş tatminini azaltırken, iş işten ayrılma niyetini arttırır (Dikili ve Bayraktaroğlu, 2013:206). Özellikle turizm işletmelerinde, çalışanların davranışları ve bu davranışa bağlı olarak değişen faktörler işletme için önem arz etmektedir. Çalışanın eğitilmesi ve yetiştirilmesi işletme için maliyetli bir süreçtir. Bu nedenle çalışanın işten ayrılma niyetinin artması, işletme için maliyet unsuru oluşturmaktadır (Gülertekin Genç ve Gümüş, 2017:212). Turizm sektöründe tecrübeli çalışanın verimliliği arttıracağı ile misafir memnuniyeti oluşturacağı söylenebilir. Bu nedenle, çalışanın işten ayrılma niyetinin artmasının, işletmenin zarara uğramasını sağlayacağını söylemek mümkündür. Çalışmanın temel amacı; algılanan otantik liderlik davranışının, psikolojik sözleşme ve işten ayrılma niyeti üzerindeki etkisinin belirlenmesidir.

\section{KAVRAMSAL ÇERÇEVE}

\section{Otantik Liderlik}

Artan rekabet ortamında, işletmelerin hedeflerini gerçekleştirebilmeleri için rakiplerine göre fark yaratmaları gerektiği söylenebilir. Bu nedenle işletmeler, insan kayağı bünyesini güçlendirerek, şeffaf, dürüst ve ahlaki değerlere önem veren liderlerle çalışır. Böylece çalışanların görevlerini yerine getirirken, aynı zamanda güven ortamının oluşturulması sağlanır (Çankaya, 2019:1488). Dürüst, yüksek düzeyde iletişim gücüne sahip, zayıf yönlerinin farkında olan ve kendini bilen liderler; çalışanlara dürüst, samimi ve içten davranır. Böylece çalışanların verimlilikleri ve örgüt bağlılıkları da arttıılmış olur. Bu özellikteki çalışanlara sahip işletmeler, rekabet ortamında daha güçlü olmaktadırlar (Işkın ve Kaygın, 2016:620). Bu ahlaki değerlere uygun davranışlar sergileyen liderlik türlerinden birisinin de otantik liderlik olduğu söylenebilir. Liderlik açısından otantik kavramı; içten, doğru, gerçek ve samimi anlamına gelmektedir (Turhan, 2007:36). Otantik liderlik; liderin, kendini geliştirerek çalışanlarla olumlu ilişki kurması ve çalışanların olumlu yönde gelişmesine katkı sağlayan liderlik türüdür (Luthans ve Avolio, 2003: 242). Otantik liderler; umut, iyimserlik, güven ve esneklik boyutlarıyla geleceğe uyumlu olabilmek için çaba 
gösterirler (Ilies vd., 2005:376). Luthans ve Avolio (2003)'e göre; Otantik liderler, dürüst, iyimser, umutlu, şeffaf, esnek, geleceğe yönelik ve gelişmekte olan çalışanlara yönelik liderliktir. Otantik liderliğin temelinde etik kurallara uymak ve güvenilir olmak vardır (Turhan, 2007: 38). Başka bir ifade ile otantik liderler; çevresindekilerde karşılıklı güven ilişkisi kuran, kişinin öz değerlerine önem veren, disiplinli, ahlaklı ve iş arkadaşlarının olmasıyla kendisi de mutlu olan liderlerdir (Akgündüz, 2012: 18). Otantik liderlik tarzını benimseyen liderler; örgütün karar alması gereken durumlarda, ahlaki değerlerin göz önünde bulundurur, bilginin ast ve üstlerle paylaşılmasını, öğütte yer alan bireylerin sahip olduğu değerleri kabul edip benimsenmesi, aynı zamanda kendi değerlerini çevresine aktararak, örgütsel sürecin ve çalışanların daha iyi yönetilmesini sağlar (Walumbwa vd., 2010:903). Aynı zamanda otantik liderlik davranışını sergileyen liderler; çalışanlara emredici veya üstünlüklerini vurgulayan tavırlar yerine, astlarına örnek olacak, motivasyonu örgütsel bağlılığı ve arttıracak davranışlar sergilerler (Lawler ve Ashman, 2012:463). Walumbwa ve arkadaşları (2008) yaptıkları çalışmada otantik liderliğin dört alt boyutta ele almıştır. Bu boyutlar; öz farkındalık, bilginin dengeli değerlendirilmesi, ilişkilerde şeffaflık ve içselleştirilmiş ahlak anlayışı şeklinde sıralanabilir. Öz farkındalık; liderin, kişisel özelliklerini, duygu ve değerlerini, güçlü ve zayıf yönlerini bilmesi ve bu farkındalığına güvenmesi olarak açıklanabilir (Tütüncü ve Akgündüz, 2014:168). Öz farkındalık, kişinin kendini tanıması, dünyayı algılama şekli ve kendini değerlendirebilmesi sonucunda olumlu ve olumsuz yönlerinin farkında olmasıdır (Gül vd., 2017: 35). Otantik liderlerin en önemli boyutunun öz farkındalık olduğunu söylemek mümkündür. Çünkü; otantik liderler, kendilerini bilirler. Aynı zamanda kendileri ve çalışanlar için neyin önemli olduğunun farkındadırlar (Nikpay vd., 2014: 65). Bu nedenle, öz farkındalık sadece lideri değil, liderin çevresindekileri de etkilediği söylenebilir. Özetle öz farkındalığın liderlin kendini bilmesi, güçlü ve zayıf yönlerinin farkında olması olarak açıklanabilir. Diğer bir boyut olan bilginin dengeli değerlendirilmesi ise; otantik liderlerin karar alırken, sahip oldukları tüm bilgiyi değerlendirmesi ve buna göre karar vermesi olarak açıklanır (Özdemir, 2017, :6). Liderin karar almadan önce farklı kişilerin görüşlerini alarak, elde edindiği bilgileri objektif değerlendirmesidir (Taşlıyan ve Hırlak, 2016:94). Bu boyutun, liderlin kararlar alırken eşit davranması ile ilgili olduğu söylenebilir. Otantik liderler, karar alırken bilginin, abartmadan, çarpıtmadan, nesnel bir şekilde değerlendirmesidir. Böylece liderin kendini yüceltme veya savunma durumda kalması söz konusunu olmayacaktır. Bilginin dengeli değerlendirilmesi, otantik liderlik davranışını benimseyen liderlerin, kişisel bütünlüğünün temelidir (Gül vd., 2017: 36). İlişkilerde şeffaflık boyutu; liderin ilişkilerinde şeffaf olmasıdır. Başka bir ifade ile liderin, çalışanlara karşı açı ve dürüst olması aynı zamanda düşüncelerini doğrudan aktarmasıdır (Ayça, 2016: 33). Otantik liderliğin, kendini açıkça ifade edebilen, düşüncelerini şeffaf bir şekilde çalışanlara aktaran liderlik tipi olduğu söylenebilir. Son olarak, içselleştirilmiş ahlaki anlayışta; otantik liderler, çalışanlara yardımcı olabilmek için ahlaki açıdan kendi yaptıklarından sorumludurlar. Liderler, çalışanlar için iyi veya kötü sonuçlar doğurabilecek davranışların tamamen farkında olarak hareket etmeli ve buna göre karar vermelidirler (Akgündüz, 2012:33).

Otantik liderlikte; öz farkındalık, bilginin dengeli değerlendirilmesi, ilişkilerde şeffaflık ve içselleştirilmiş ahlaki anlayış boyutlarına sahip liderler, etik kurallarına uygun davranmaları ve kişisel görüşleriyle tutarlı olmaları nedeniyle çalışanların güvenini ve saygısını kazanmış olurlar (Özdemir, 207:7). Konaklama işletmeleri emek yoğun işletmeler olması nedeniyle, çalışanların müşterilerle ilişkileri olukça önemlidir. Çalışanın işe karşı olan tutumda liderin sergilemiş olduğu davranışların etkili olduğunu söylemek mümkündür. Otantik liderler, güvenilir, esnek 
ve ahlaki kurallar çerçevesinde davranışlar sergileyerek, çalışanların güvenini kazanırlar (Tabak vd., 2012: 93). Böylece çalışanın işe bağlılığını ve performansını artırabilirler.

\section{Psikolojik Sözleşme}

Psikolojik sözleşme; çalışan ile işletmenin birbirini anlamasına yönelik bir kavramdır. Psikolojik sözleşme kavramı ilk olarak 1960 yılında, Argyris tarafından kullanılmıştır. Argyris (1960), çalışan performanslarını arttırmak için yazılı anlaşmaların dışında farklı ilişkilerin de önemli olduğunu ifade etmiş, ancak o farklı ilişkilere tam olarak açıklık getirememiştir (Akbaba, 2018: 321). Teknolojinin gelişmesiyle ile rekabetin ortamı artmış ve müşteri beklentileri de değişmiştir. $\mathrm{Bu}$ nedenle psikolojik sözleşme, daha çok performansın geliştirilmesi açısından kullanılmıştır (Özdaşlı ve Çelikkol, 2012:142). İlgili literatür incelendiğinde, Rousseau'un psikolojik sözleşme kavramını geliştirdiği görülmektedir. Daha sonra yapılan çalışmalarda ise Rausseau'un görüşlerinin benimsendiği görülmüştür (Rousseau ve Tijoriwala, 1998:681). Literatürde psikolojik sözleşme için farklı tanımlar yer almaktadır. Rousseau ve Schalk, psikolojik sözleşmeyi "istihdamda işletme ve çalışan arasındaki karşılıklı yükümlülüklere dayalı bireylerin inanç sistemleri" olarak açıklamıştır (Salha vd., 2016: 49). Psikolojik sözleşme, resmi sözleşmelerden farklı olarak, algısal yönü olan bir sözleşme türüdür (Robinson, 1996:575). Millward ve Brewerton (1999); çalışan ile işletme arasında karşılıklı yükümlülükler içeren anlaşma, Levinson ve arkadaşarı (1962) ise; çalışan ve işletme arasında yazılı veya sözlü olmayan, karşılıklı beklentiler, olarak tanımlamıştır. Psikolojik sözleşmenin oluşturulmasında bazı kaynaklar rol almaktadır. Genel olarak bakıldığında, çalışan işe alındığında işe alan kişi ile çalışan etkileşimde bulunarak bu sözleşmeyi gerçekleştirebilmektedir. Aynı zamanda çalışan, işletmede işe başlamadan önce, yazılı basın, aile üyeleri veya arkadaş çevresinden edindiği bilgilerden yararlanarak psikolojik sözleşme gerçekleştirebilir (Akbaba, 2018:321). Çalışanlar açısından olumlu bir psikolojik sözleşme için bazı koşullar vardır. Bunlar; işin niteliği, çalışanın ödüllendirilmesi, kariyer gelişimine olanak sağlanması ve işin başarılı bir şekilde gerçekleştirilebilmesi için kişisel desteğin olması, çalışanların özel hayatına saygı gösterilmesi ve işbirliği ortamının sağlanmasıdır (Arslan ve Ulaş, 2004:103). Yapılan araştırmalar sonucunda iki tür psikolojik sözleşme türü olduğu tespit edilmiştir (Rousseau, 1990: 391). Bunlar; işlemsel ve ilişkisel psikolojik sözleşme olarak adlandırılır (Rousseau, 1990: 391). Daha sonra değişen örgüt koşulları göz önünde bulundurularak, Rosseau (1995), tarafından geçişsel ve dengeli olmak üzere iki sözleşme türü daha eklenmiştir (Aydın, 2016:47). Böylece psikolojik sözleşme toplamda dört alt boyutta incelenmiştir. Bu boyutlar; işlemsel psikolojik sözleşme, İlişkisel psikolojik sözleşme, dengeli sözleşme ve geçici sözleşme olarak sıralanmaktadır. İşlemsel psikolojik sözleşme; daha çok maddi faktörlerin önemli olduğu kısa süreli sözleşmelerdir (Özdaşlı ve Çelikkol, 2012:145). İşlemsel sözleşmenin en önemli özellikleri, çalışanın yükümlülüğünün az olması ve sözleşmenin kısa süreli olmasıdır (Dabos ve Rousseau, 2004:58). Sözleşme kapsamında, çalışan işletmede kalıcı değildir ve bu nedenle yükümlülükleri sınırlıdır, buna bağlı olarak işveren belirli süre için istihdam sağlamakta, gelecek için garanti verememektedir (Akbaba, 2018:322). İşlemsel sözleşmeler için, maddiyatın ön planda olduğu, geçici süreliğine istihdam sağlandığı, bu nedenle çalışanın yükümlülüklerinin sınırlı olduğunu söylemek mümkündür. Başka bir boyut olan ilişkisel psikolojik sözleşmede ise; karşllıklı çıar ve maddi olmayan unsurların ön planda olduğu, uzun vadeli ilişkilerin inşa edilmesi sürecinde, geleceğe yönelik çalışan istihdamı söz konusudur. Sözleşme sürecinde, çalışan sürekli olarak aynı işte çalışması ve kendisine verilen 
görevleri yerine getirmekle yükümlüdür. Çalışanın işletme çıkarlarını düşünmesi, işletmeyi desteklemesi ve örgüte bağlı bir çalışan olması gerekir. Buna karşılık olarak İşletme sahibi de çalışanların çıkarlarını ve refahını üstlenmiştir (Rousseau, 2000:4). İlişkisel sözleşme türünde, iş güvencesinin sağlanması, eğitim ve gelişim olanaklarının sunulması karşısında, çalışanın işletmeye karşı sadık ve bağlı olması beklenmektedir (Çolakoğlu, 2016:46). Dengeli sözleşme; uzun dönemli fakat maddi unsurların önemli olduğu, buna karşılık iş yükümlülüklerinin yerine getirilmesine dayanan sözleşme türüdür (Özdaşlı ve Çelikkol, 2012:145). İşlemsel ve ilişkisel sözleşme türlerinden farklı olarak günümüzde en çok tercih edilen sözleşme türün olduğu söylenebilir. Çalışan görevini yerine getirirken gerek duyacağı yeteneklerini geliştirmek için çaba harcaması gerekir ve bu amaçla kariyer gelişimi veya yükselme gibi olanaklar gerçekleşir. Bu durumda işveren ve çalışan arasındaki katkılar dengelenir (Millward ve Hopkins:1998). Son boyut olan geçici sözleşmenin; kısa vadeli, geçici ve performansla ilgisi olmayan sözleşmeler olduğu söylenebilir. Bu sözleşme türü genellikle, işletmenin el değiştirmesi, kriz dönemi, büyüme veya küçülme stratejisi uygulanması gibi belirsizliklerin yaşandığı dönemlerde sıkça kullanıldığı görülmektedir bu nedenle çevresel faktörlere bağlı olarak değişebilen ve garantisi olmayan sözleşme türünü ifade eder (Aydın, 2016: 47). Geçici sözleşmeler, psikolojik sözleşmeden çok, çalışan ve işveren arasında bilişen bir durum olarak ortaya çıkan sözleşme türüdür (Millward ve Hopkins, 1998:1541).

\section{İşten Ayrılma Niyeti}

İşten ayrılma niyeti; çalışanın sergilediği davranışlar ve bu davranışlara bağlı faktörler işletme için önemli bir sorun niteliğindedir. İşletmeler çalışanları yetiştirmek için, çaba harcarlar, bu nedenle çalışanların eğitilmesinin işletmeler için zor olduğu söylenebilir. Özellikle turizm işletmelerinde işten ayrılma büyük bir maliyet unsurudur (Genç ve Gümüş, 2017:212). Turizm sektöründe yer alan işletmeler için, çalışanın tecrübesi önem arz etmektedir, kalifiyeli bir personelin işletmeden ayrılması işletme için büyük kayıp olacağını söylemek mümkündür. Subramanian ve Shin (2013), işten ayrılmanın bilinçli davranış olduğunu ve bu davranışı sergileyen çalışanların, başka iş olanakların değerlendirdiklerini ifade etmiştir. Tett ve Meyer (1993) ise, işten ayrılma niyetini, işletmeden ayrılmanın önceden düşünülmüş bilinçli bir karar olduğunu, Rusbelt ve Rogers (1988) ise, çalışanların, çalışma koşullarından memnun olmamaları durumunda gösterdikleri davranış olarak ifade etmiştir. İşten ayrılma, işletme yöneticileri açısından çoğu zaman olumsuz bir durumu ifade etse de bazı durumlarda olumlu sonuç olarak nitelendirilir (Tanrıverdi vd., 2016:119). İşten ayrılma niyeti, cinsiyet, yaş, tazminat, görev süresi, eğitim, tecrübe, görev süresi gibi faktörlerden kaynaklanabilir (Sökmen ve Sezgin, 2017: 240). İşten ayrılma niyeti, işletmeler ve çalışanlar açısından önemli bir sorundur. İşletme açısından bakıldığında, deneyimli personel bulma zorluğu, personel eğitme be uyum sağlama problemi gibi oldukça maliyetli sonuçlar doğururken, çalışan açısından bakıldığında, işsiz, ailevi problemler, gelir kaybı, işletmeye harcanan emeklerin boşa gitmesi düşüncesi, başka bir işletmeye uyum zorluğu gibi sorunlar oluşturmaktadır (Türk ve Akbaba, 2017:468). İşletme ve çalışan açısından, çoğu zaman olumsuz sonuçlara sebep olan işten ayrılma niyetini etkileyen unsurlar tespit edilerek, bu unsurların en aza indirgenmesi önemlidir (Avcı ve Küçükusta, 2009: 37). Personel devir hızının yüksek olduğu işletmelerde, müşterilere kaliteli hizmet sunmak, müşteri memnuniyeti, müşteri ile iletişim kurmak gibi işletmenin itibarı açısından önemli konularda sorunlar yaşanabilir (Dalgıç, Akgündüz, 2019:78). 


\section{Otantik Liderliğin Psikolojik Sözleşme ve İşten Ayrılma Niyeti Üzerindeki Etkisi}

Konaklama işletmelerinde, çalışanın olaylara bakış açısı, işe bağlılı̆̆ı, işe karşı sergilediği tutum ve davranışlar, çalışının iş tanımına uygun olması gibi unsurların, verimliliği arttıracağını söylenebilir. Bu unsurlar ise işletmenin yönetiminden kaynaklanır. İşletme yönetimini oluşturan en önemli unsur ise liderlerin sergilemiş oldukları davranış biçimleridir (Cinnioğlu ve Güler, 2020:768). İlgili literatür incelendiğinde, Flood ve arkadaşlarının (2008), yaptıkları çalışmada, liderlik tarzlarının, psikolojik sözleşmenin oluşturulmasında etkili role sahip olduğunu belirtmişlerdir. Epitropaki (2013), dönüşümcü ve etkileşimci liderlik türlerinin psikolojik sözleşmeye dolaylı etkisi olduğunu, Gerçek (2017) ise, yöneticiler açısından psikolojik sözleşmenin dönüşümcü ve etkileşimci liderlik tarzları ile pozitif yönlü ilişkiye sahip olduğunu tespit etmiştir. Başka bir çalışmada ise; otantik liderlik ile iş tatmini ve örgütsel bağlılık arasında pozitif yönlü ilişki olduğu, çalışanların iş tatmini arttıkça örgüte olan bağlllıklarının da arttığ 1 tespit edilmiştir (Ayça, 2016: 65). Kuramsal yapıda da belirtildiği üzere, otantik liderlik tarzını benimseyen liderler, etik kurallara uygun hareket ederler ve örgütte güven ortamı oluşturarak çalışanların motivasyonunu ve işe bağlılıklarını arttırlar. Hırlak ve Taşlıyan (2016) otantik liderliğin, işten ayrılma niyeti üzerindeki etkisini tespit etmeye yönelik yaptıkları çalışmanın sonucunda, otantik liderliğin, işten ayrılma niyetini negatif yönde etkilediğini belirtmişlerdir. Tanrıverdi ve arkadaşları (2016), dönüşümcü liderlik davranışının, işten ayrılma niyetini olumsuz yönde etkilediğini, Afacan (2014) ise algılanan liderlik desteğinin, işten ayrılma niyetini negatif yönde etkilediğini tespit etmiştir. İşten ayrılma niyeti ile örgüt iklimindeki olumsuz durumlar arasında ilişki vardır ve işten ayrılma niyeti genellikle işletmeler açıcından olumsuz sonuçlar doğurabileceğinden istenmeyen bir kavramdır. Bu nedenle işten ayrılmanın habercisi olan işten ayrılma niyetinin önceden anlaşılıp sorun ne ise çözülmesi önerilir (Genç ve Gümüş, 2017:213). Konuyla ilgili literatürde yer alan çalışmalar incelendiğinde H2 hipotezi ve araştırma modeli oluşturulmuştur.

Yapılan çalışmalardan yararlanılarak $\mathrm{H} 1$ ve $\mathrm{H} 2$ hipotezleri geliştirilmiştir.

H1: Algılanan otantik liderlik davranışı, psikolojik sözleşme düzeyini pozitif yönde etkilemektedir.

H2: Algılanan otantik liderlik davranışı, işten ayrılma niyetini negatif yönde etkilemektedir.

Şekil 1. Araştırma Modeli

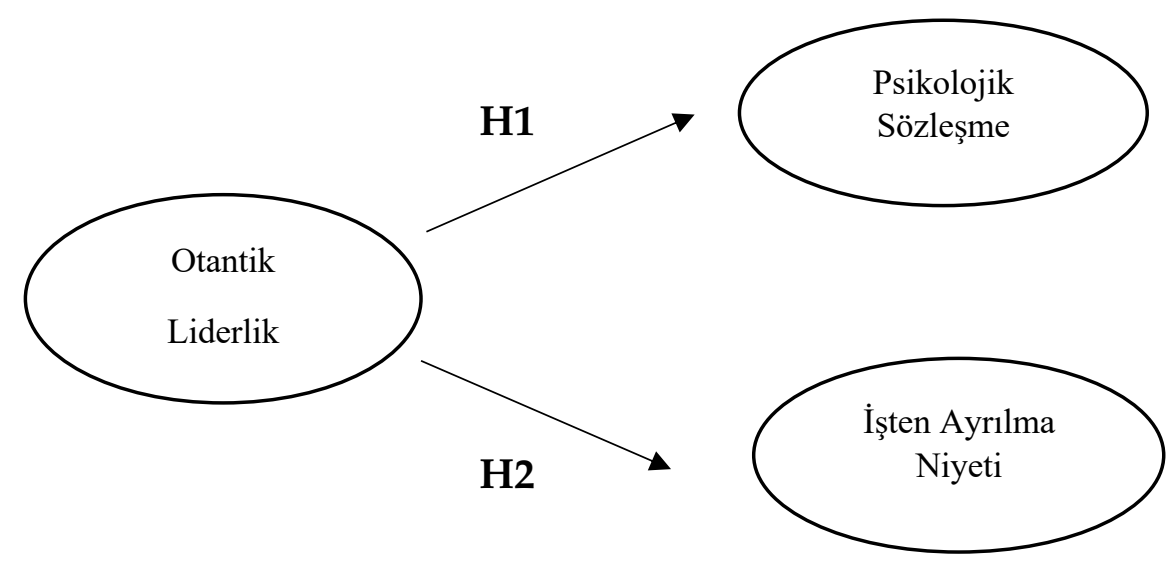




\section{YÖNTEM}

Araştırmada ilişkisel tarama modelinden yararlanılmıştır. Araştırmanın yönteminde; araştırmanın amacı ve önemi, veri toplama aracı, evren ve örneklem yer almaktadır.

\section{Araştırmanın Amacı ve Önemi}

Konaklama işletmeleri, emek yoğun çalıştıklarından personelin tutum ve davranışları, işe bağlllı̆̆ı, iş tatmini ve yaptığ 1 işten memnun olmasının önem arz ettiğini söylemek mümkündür. İşletme yönetiminde yer alan liderlerin tutum ve davranışları, çalışanların ve işletmenin verimliliğini arttırabilir. Çalışanlar, işletmenin hedeflerine ulaşabilmesi için duygusal ve fiziksel güçlerini kullanırlar (Cinnioğlu ve Saçlı, 2019:1771). Otantik liderlik anlayışını benimseyen liderler, işletmede güven ortam oluştururlar ve etik kurallara uygun davranırlar, aynı zamanda karar alırken farklı kişilerin görüşlerini alarak bilgileri objektif değerlendirip tarafsız kararlar alırlar. Otantik liderler çalışanların olumlu yönde gelişmesine katkıda bulunurlar böylece çalışanların motivasyonu işe bağlılıklarını arttırlar (Turhan, 2007:38; Taşlıyan ve Hırlak, 2016:94; Çankaya, 2019: 1488). Otantik liderlik davranışını sergileyen liderler, kendileri bilen, inançlarının ve değer yargılarının farkında olan, etik, şeffaf ve tutarlı davranan çalışanlarla, güven, esnek ve iyimser ilişki kuran kişilerdir (Avolio vd., 2005:23). Araştırmada; algılanan otantik liderlik davranışının, psikolojik sözleşme ve işten ayrılma niyeti üzerindeki etkisini belirlemek amaçlanmıştır.

\section{Evren ve Örneklem}

Araştırmanın evreni Antalya ilinde faaliyet gösteren beş yıldızlı otel işletmeleri olarak seçilmiştir. Antalya ilinde 219 beş yıldızlı otel bulunması (antalya.ktb.gov.tr) ve bu otellerin kurumsal olmaları nedeniyle güvenilir bilgiler elde edilebileceği düşüncesiyle evren seçilmiştir. Otellerde çalışan sayısı tam olarak bilinememesi nedeniyle sınırsız evren kabul edilmiştir. Bu nedenle sınırsız evrende kabul edilen 384 kişi örneklem olarak seçilmiştir (Altunışık vd., 2005:123). Örneklem, beş yıldızlı otellerde farklı departmanlarda çalışan basit tesadüfi yöntem ile 384 kişi seçilmiştir. Anket çalışması Kasım 2019 ile Haziran 2020 tarihleri arasında yapılmıştır. Toplamda 475 tane anket dağıtılmış olup 448 ankette geri dönüş sağlanmıştır. Ancak bu anketlerden eksik ve hatalı anketler çıkartılarak toplamda 402 anket analiz edilmiştir.

\section{Veri Toplama Aracı}

Araştırmada, veri toplama aracı olarak anket tekniğinden yararlanılmıştır. Hazırlanan anket toplamda dört bölümden oluşmuştur. İlk bölümde otantik liderlik algısını ölçmek üzere ifadeler, ikinci bölümde psikolojik sözleşme algısını ölçemeye yönelik ifadeler ve üçüncü bölümde işten ayrılma niyetini ölçmeye yönelik ifadeler yer alırken son bölümde kişilerin demografik özelliklerini belirlemeye yönelik ifadeler bulunmaktadır. Ankette 5'li Likert yönteminden yararlanılmıştır. 


\section{Otantik Liderlik Ölçeği}

Otantik liderlik ölçeği, Walumbwa ve arkadaşları (2008) tarafından geliştirilen, Tabak ve arkadaşları (2012) tarafından çevirisi yapılan ve birçok çalışmada kullanılan (Tabak vd., 2012; Işkın ve Kaygın, 2016; Gül vd., 2017; Çankaya, 2019) ölçek; şeffaflık, ahlaki davranış, dengeli davranış ve bireysel farkındalık olmak üzere dört boyuttan oluşmaktadır. Ankette toplama 16 ifade yer almaktadır (Ödemir, 2017:54). Anket ifadelerinin ilk beş maddesi ilişkilerde şeffaflık, 6 . ile 9. ifadeleri arası içselleştirilmiş ahlaki anlayışı, 10 ile 12. ifadeler, bilginin dengeli değerlendirilmesi ve 13 ile 16. İfadeler öz farkındalık boyutlarını ölçmektedir.

\section{Psikolojik Sözleşme Ölçeği}

Psiklojik sözleşme ölçeği, Millward ve Hopkins (1998) tarafından geliştirilen, Mimaroğlu (2008) tarafından Türkçeye çevirisi yapılan toplamda 17 ifadeden oluşan ölçek kullanılmıştır. Ölçeğin ilk 10 maddesinde psikolojik sözleşmenin işlemsel boyutunu ölçemeye yönelik ifadeler yer alırken, diğer 7 madde ise ilişkisel boyutu ölçmeye yönelik ifadeler bulunmaktadır. Ölçek birçok çalışmada kullanılmış (Özgen ve Özgen, 2010; Nam, 2018; Çiçekoğlu ve Taşlıyan, 2018), geçerliliği ve güvenilirliği analiz edilmiştir.

\section{İşten Ayrılma Niyeti Ölçeği}

Çalışanların işten ayrılma niyetini ölçmek amacıyla, Camman ve arakadaşları (1979) tarafından geliştirilen ve toplamda 3 ifadeden oluşan ölçek kullanılmıştır. Ölçeğin geçerlilik ve güvenilirliği sağlanmıştır (Tanrıverdi vd., 2018: 12). Ölçek birçok farklı çalışmada kullanılarak geçerlilik ve güvenilirlik analizleri yapılmıştır (Tanrıverdi vd., 2016: 117; Genç ve Gümüş, 2017:214; Tanrıverdi vd., 2018:122; Okşit ve Kılıç, 2019:52).

Katılımcların demografik özellikleri incelendiğinde, \%77'sinin erkek (n=310), \%43'ü 26-35 yaş arasında ( $n=173)$ ve \%39'u önlisans mezunu ( $n=157)$ olduğu görülmektedir. Bu katılımcıların \% 36'si 6-10 yıl arasında ( $n=145)$ otelcilik tecrübesine sahipken \% 44'ü mevcut işletmede 1-3 yıl arasında ( $\mathrm{n}=177)$ çalışmaktadır. Bununla birlikte katılımcıların \% 68' inin turizm $(\mathrm{n}=273)$ ile ilgili eğitimi mevcutken, \% 56'si yiyecek içecek $(n=225)$ bölümünde görev yapmaktadır.

\section{BULGULAR}

Araştırmada ankette yer alan ölçeklerin faktör yapısının uygunluğu belirlemek amaciyla doğrulayıcı faktör analizi (DFA) yapılmıştır. Ancak doğrulayıcı faktör analizi yapmadan önce ölçeklerin faktör analizine uygunluğu Kaiser Meyer Olkin (KMO) örneklem yeterliliği testi ve Barlett's küresellik testi sonuçlarına göre belirlenmiştir. Yapılan analizler neticesinde otantik liderlik ölçeğinin KMO değeri 0.842 , psikolojik sözleşme ölçeğinin 0.811 ve işten ayrılma ölçeğinin ise 0,892 olduğu ve aynı zamanda tüm ölçeklerin Barlett's değerinin ise 0,000 olduğu belirlenmiştir. Ölçeklerin KMO test değerinin 0,60'dan büyük olması ve Bartlett testi $\mathrm{p}$ istatistik önem düzeyinin 0,05'ten küçük olmasından dolayı araştırmada kullanılan ölçeklerin faktör analizine uygun olduğu ifade edilebilir (Durmuş vd., 2018). Uygunluk belirlendikten sonra 
ölçeklere doğrulayıcı faktör analizi yapılmıştır. Ölçeklere yönelik yapılan doğrulayıcı faktör analizi sonuçları tablo 1'de verilmiştir. Bu değerlere bakıldığında araştırmada kullanılan ölçeklerin uyum iyiliği değerlerinin kabul edilebilir düzeyde olduğu görülmektedir (Meydan ve Şeşen, 2015:23).

Tablo 1. Ölçeklere Yönelik Yapılan Doğrulayıcı Faktör Analizi Uyum İndeksi Sonuçları

\begin{tabular}{|l|l|l|l|l|l|}
\hline $\begin{array}{l}\text { Uyum } \\
\text { Indeksleri }\end{array}$ & $\begin{array}{l}\text { İyi } \\
\text { Uyum }\end{array}$ & $\begin{array}{l}\text { Kabul } \\
\text { Edilebilir } \\
\text { Uyum }\end{array}$ & $\begin{array}{l}\text { Otantik } \\
\text { Liderlik } \\
\text { Ölçeği }\end{array}$ & $\begin{array}{l}\text { Psikolojik } \\
\text { Sözleşme } \\
\text { Ölçeği }\end{array}$ & $\begin{array}{l}\text { İsten } \\
\text { Ayrılma } \\
\text { Ölçeği }\end{array}$ \\
\hline $\begin{array}{l}\text { CMIN/DF } \\
(x 2 / s d)\end{array}$ & $\leq 3$ & $\leq 4-5$ & 3,38 & 4,01 & 2,80 \\
\hline NFI & $\geq 0.95$ & $0.94-0.90$ & 0,95 & 0,92 & 0,96 \\
\hline RMSEA & $\leq 0.05$ & $0.06-0.08$ & 0,06 & 0,07 & 0,05 \\
\hline GFI & $\geq 0.90$ & $0.89-0.85$ & 0,90 & 0,88 & 0,93 \\
\hline AGFI & $\geq 0.90$ & $0.89-0.85$ & 0,89 & 0,89 & 0,91 \\
\hline CFI & $\geq 0.97$ & $\geq 0.95$ & 0,96 & 0,95 & 0,97 \\
\hline TLI & $\geq 0.95$ & $0.94-0.90$ & 0,94 & 0,93 & 0,95 \\
\hline IFI & $\geq 0.95$ & $0.94-0.90$ & 0,94 & 0,93 & 0,95 \\
\hline
\end{tabular}

Araştırmada kullanılan ölçeklere yönelik doğrulayıcı faktör analizi yapıldıktan sonra, ölçeklerin Cronbach's Alfa değeri (güvenirlilik değeri) hesaplanmış ve sonuçlar tablo 2'de gösterilmiştir. Yapılan analizler neticesinde otantik liderliğin Cronbach's Alfa değeri 0,811; psikolojik sözleşme ölçeğinin liderliğin 0,801 ve işten ayrılma niyetin ise 0,856 olarak tespit edilmiştir. Genellikle sosyal bilimlerdeki araştırmalarda Cronbach alfa $(\alpha)$ katsayısının 0.80 ve üzerinde olması, güvenirliliğin yüksek olduğu anlamına gelmektedir (İslamoğlu ve Alnıaçık, 2014: 283). Değişkenler arasındaki ilişkileri belirlemeye yönelik yapılan korelasyon analizi sonuçları Tablo 2 'de verilmiştir. Analiz sonuçlarına bakıldığında otantik liderlik ile psikolojik sözleşme algısı arasında pozitif yönlü (r: ,744), ve işten ayrılma niyeti ile arasında ise negatif yönlü (r: -,483) ilişkiler görülmektedir. Psikolojik sözleşme ile işten ayrılma arasında da negatif yönlü $(\mathrm{r}:-, 311)$ bir ilişki tespit edilmiştir. Aynı zamanda aynı tabloda çalışanların otantik liderlik $(3,41)$ ve psikolojik sözleşme algılarının $(3,03)$ orta düzeyde, işten ayrılma niyeti düzeylerinin ise düşük $(2,01)$ seviyede olduğu görülmektedir.

Tablo 2. Değişkenlere Ait Korelasyon Analizi Sonuçları

\begin{tabular}{|lcclllll|}
\hline Değişkenler & $\mathbf{n}$ & Ortalama & $\begin{array}{l}\text { Cronbach's } \\
\text { Alfa }\end{array}$ & $\mathbf{1}$ & $\mathbf{2}$ & $\mathbf{3}$ \\
\hline 1)-Psikolojik Sözleşme & 402 & 3,03 &, 801 & 1 & & \\
2)-İşten Ayrılma Niyeti & 402 & 2,01 &, 856 &,$- 311^{* *}$ & 1 & \\
3)-Otantik Liderlik & 402 & 3,41 &, 811 &, $744^{* *}$ &,$- 483^{* *}$ & 1 \\
**.p p<.001 değerinde anlaml. & & & & & \\
\hline
\end{tabular}


Şekil 2'de araştırma modeline yönelik olarak yapılan yapısal eşitlik modellemesi görülmektedir. Araştırma modelinin uyum iyiliği değerleri incelendiğinde (CMIN/DF= 3,16; RMSEA= ,08; GFI= ,89; $\mathrm{AGFI}=$,89; CFI= ,96; TLI= ,92; IFI= ,95) kabul edilebilir düzeyde olduğu görülmektedir.

Şekil 2. Yapısal Eşitlik Modeli

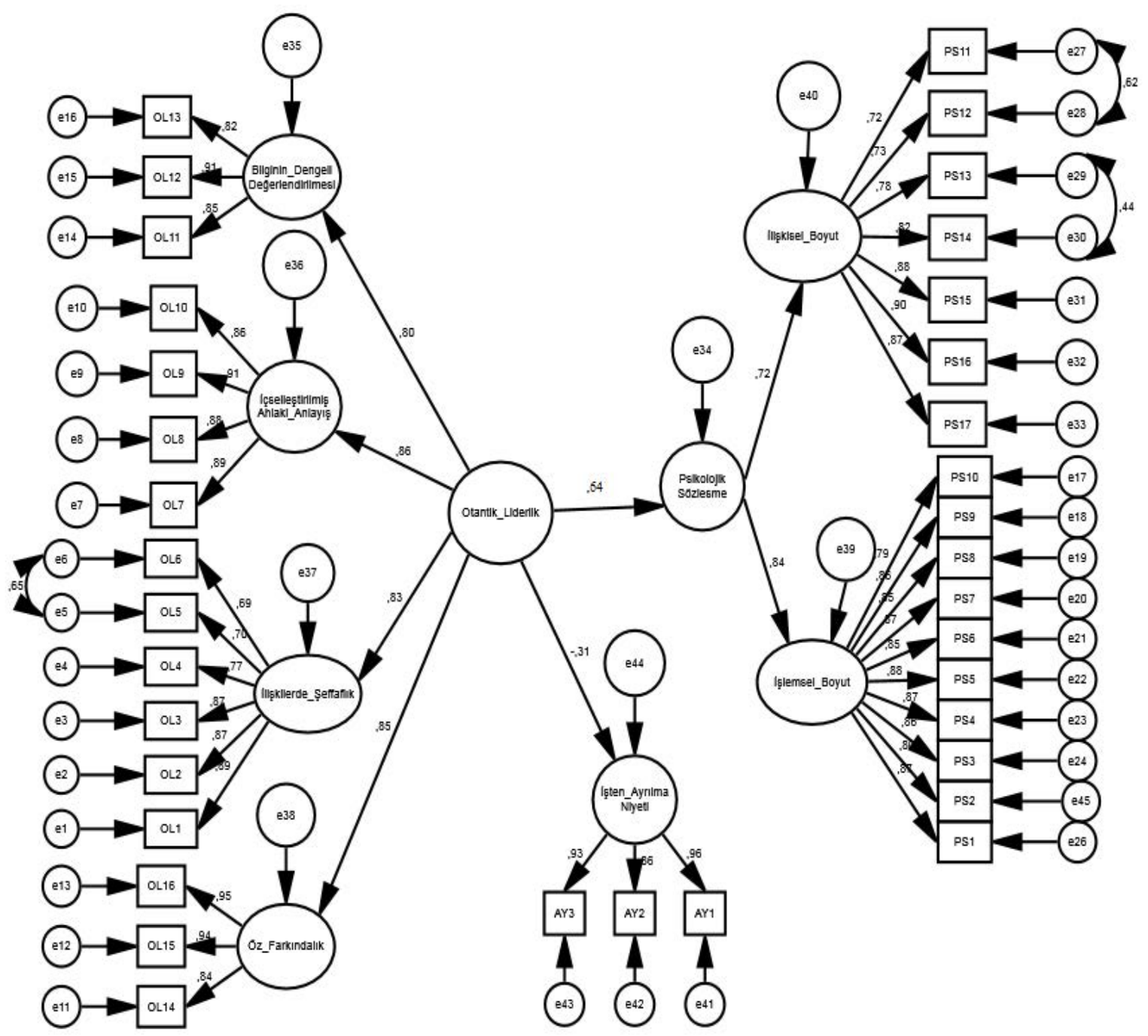

Tablo 3'teki hipotez testi sonuçları incelendiğinde algılanan otantik liderlik algısının psikolojik sözleşme düzeyini pozitf ve anlamlı $(\beta=0,64 ; p=0,00)$, işten ayrılma niyetini ise negatif ve anlamlı $(\beta=-0,31 ; p=0,00)$ bir şekilde etkilediği görülmektedir. Bu sonuçlara göre araştırmada geliştirilen $\mathrm{H} 1$ ve $\mathrm{H} 2$ hipotezleri desteklenmiştir.

Tablo 3. Hipotez Testi Sonuçları

\begin{tabular}{|c|c|c|c|c|c|}
\hline Test Edilen Yollar & $\begin{array}{l}\text { Standardize } \\
\text { Edilmiş } \\
\text { Regresyon } \\
\text { Ağırlıklar }\end{array}$ & Sta.Hata & $\begin{array}{l}\mathrm{T} \\
\text { Değeri }\end{array}$ & $\mathrm{p}$ & Sonuç \\
\hline $\begin{array}{l}\text { Otantik Liderlik } \longrightarrow \text { Psikoljik } \\
\text { Sözleşme }\end{array}$ & 0,64 & 08 & 10,28 & 000 & Desteklendi. \\
\hline $\begin{array}{lll}\text { Otantik Liderlik } & \longrightarrow & \text { İşten } \\
\text { Ayirılma Niyeti } & & \end{array}$ & $-0,31$ & 10 & $-5,69$ & ,000 & Desteklendi. \\
\hline
\end{tabular}




\section{TARTIŞMA SONUÇ ve ÖNERILER}

Araştırmanın temel amacı; Antalya ilinde faaliyet gösteren beş yıldızlı otel işletmelerinde otantik liderlik davranışı algısının, psikolojik sözleşme ve çalışanın işten ayrılma niyetine olan etkisini ölçmektir. Bu amaç kapsamında, literatürde yer alan daha önceki çalışmalardan yararlanılarak kavramsal yapı oluşturulmuştur ve kavramsal yapıya bağlı kalınarak araştırmanın hipotezleri geliştirilmiştir. Elde edilen hipotezlerin analizi için, Antalya ilinde faaliyet gösteren beş yıldızlı otel çalışanları üzerinde yapılan araştırma sonucunda, eksik ve hatalı anketlerin çıarılması sonucunda toplamda 402 anket toplanmış ve analiz edilmiştir. Analizler sonucunda; algılanan otantik liderlik davranışının psikolojik sözleşmeyi pozitif yönde etkilediği sonucuna varılmıştır. Literatürde yer alan daha önceki çalışmalar incelendiğinde, farklı liderlik türleri ile yapılan çalışmalarda, benzer bulgular tespit edilmiştir. Turizm sektöründe, otantik liderlik üzerinde yapılan sınırlı sayıda çalışma bulunmaktadır (Şimşek vd., 2017:101). Otantik liderlik davranışını sergileyen liderler; düşünce ve davranışlarının, çalışanlar tarafından nasıl algılandığının farkında olan, güçlü ve zayıf yönleri iyi bir şekilde bilen, güvenli çalışma ortamı oluşturabilen, iyimser, kendine güvenen, çalışanların motivasyonunu arttırarak iş tatminini oluşturan, sorunlara hızlı çözüm üreten, ahlak sahibi kişilerdir. (Kesken ve Ayyıldız, 2008:737). Böylelikle örgütte güven ortamı oluşur ve çalışanlar, yapılan psikolojik sözleşmenin gerçekleşeceği algısına sahip olurlar. Başka bir ifade ile otantik liderliğin psikolojik sözleşme ihlalini negatif yönde etkilediğini söylemek mümkündür. Türk ve Akbaba (2018) yaptıkları çalışmada, etik liderliğin psikolojik sözleşme ihlalini negatif yönde etkilediğini tespit etmişlerdir. Etik liderlik; çalışanının motive edilmesini sağlayan davranışlar sergilerken aynı zamanda iş tatmini ve örgütsel güveni de arttırır (Türk ve Akbaba, 2018:403). Buna göre etik liderlik ile otantik liderliğin benzer özelliklere sahip olduğu söylenebilir.

Çalışmada elde edilen başka bir bulgu ise; otantik liderlik ile psikolojik sözleşme arasında pozitif yönlü ilişki olduğudur. Daha önceki yapılan çalışmalar incelendiğinde (Flood vd., 2008; Epitropaki, 2013; Gerçek, 2017) elde edilen bulguların örtüştügü görülmektedir. Otantik liderler; kendi statü, onur ve kişisel çıkarları yerine, işletmenin ve çalışanların çıarlarını ön planda tutarlar ve çalışanları motive ederler (Avolio ve Gardner, 2005:321). Otantik liderlik davranışını sergileyen liderler, ilişkilerinde şeffaf davranarak, çalışanlara karşı açık ve şeffaf olduklarını söylemek mümkündür. Başka bir ifade ile otel işletmelerinde; liderin etik davranışlara uygun davranması, ilişkilerinde şeffaf olması, işletmede güven ortamı oluşturması ve öz farkındalığa sahip olması; çalışanların kariyer gelişiminde katkıda bulunur ve kişisel gelişimlerine destek olurken aynı zamanda çalışanların özel hayatına saygı gösterir. Böylelikle çalışanın işletmeye olan güvenini arttırır ve psikolojik sözleşmede yer alan maddeler gerçekleşeceği algısına sahip olurlar.

Yapılan analizler sonucunda elde edilen başka bir bulgu ise, otantik liderliğin işten ayrılma niyetini negatif yönde etkilediğidir. Literatürde yer alan daha önceki çalışmalar incelendiğinde; Suskind ve arkadaşlarının (2000) da yaptıkları çalışmanın sonucuna göre; işten ayrılma niyeti ile örgütsel bağlllık arasında ilişki olduğunu söylemek mümkündür. Kara ve arkadaşlarının (2013) yaptıkları çalışmada ise dönüşümcü liderlik davranışının örgütsel bağlılığı pozitif yönde arttırdığı sonucuna varmışlardır. Işkın ve Kaygın (2016) yaptıkları çalışma sonucunda, Otantik liderlik davranışı ile örgütsel bağlılık arasında pozitif yönlü anlamlı bir ilişki olduğunu tespit etmişlerdir. Tanrıverdi ve arkadaşları (2016) ise yapmış olduğu çalışma sonucunda, dönüşümcü liderliğin işten ayrılma niyetini negatif yönde etkilediği sonucuna varmışlardır. Otantik liderler, 
kendilerinin ve çalışanlarının güçlü ve zayıf yönlerini çok iyi bilen kişilerdir (Gardner vd., 2005: 349). Otantik liderlik davranışını sergileyen liderler; çalışanlar için neyin önemli olduğunun farkında olurlar, çalışanların güçlü ve zayıf yönlerini çok iyi bilirler ve buna göre davranışlar sergilerler. Başka bir ifade ile çalışanların örgüte olan bağlılığını arttırırlar. Otantik liderler, çalışanların düşüncelerini söylemesi için cesaretlendirir ve çalışanın özel durumlarının onları nasıl etkilediğini anlar ve bunu onlara belli eder (Avolio vd., 2005). Böylelikle otantik liderlik davranışı sergileyen liderler, çalışan düşüncelerini özgürce ifade edebilmelerine, olanak sağlayabilirler.

Elde edilen başka bir bulgu ise psikolojik sözleşme ile işten ayrılma niyeti arasında da negatif yönü bir ilişki tespit edilmiştir. Kuramsal yapıda da bahsedildiği gibi, psikolojik sözleşme, çalışanlar ile işletme arasında gerçekleştirilen karşlıklı çıkarları içeren sözleşmedir. Çalışan haklarının ön planda olduğu ve çalışanın duygusal anlamda anlaşıldığı işletmelerde, çalışanın işletmeye ve yaptığı işe bağlılığı artar, böylelikle işten ayrılma niyetinin azalacağı söylenebilir. İşletme yöneticilerinin, çalışanın beklentileri ve isteklerini karşılayıp sözleşmeye bağlı kaldıklarında, çalışan haklarını ön planda tuttuklarında, çalışanın güvenini de kazanmış olurlar.

Otel işletmeleri emek yoğun çalı̧̧ma prensibine sahip olan işletmelerdir. Bu nedenle insan kaynağının işletme açısından oldukça önemli bir unsur olduğunu söylemek mümkündür. Liderin sergiledikleri tutum ve davranışlar, çalışanların örgüte karşı olan düşüncelerini, verimliliği, örgüt bağlılığını etkilediği söylenebilir. Başka bir ifade ile otel işletmeleri yöneticilerinin etik kurallara uygun davranması, ilişkilerinde şeffaf olması, dürüst ve açık olması, karar alırken sahip olduğu bilgiyi doğru ve objektif bir şeklide değerlendirmesi, aynı zamanda kendi güçlü e zayıf yönlerinin farkında olarak liderlik davranışları sergilemesi, çalışanı motive etmesi ve çalışanın kendini geliştirebilmesi için destek olması; verimliliği arttırırken aynı zamanda çalışanın örgüte bağlı olmasını ve güven duygusunun oluşmasını sağlar ve motivasyonu arttırır. Bu çalı̧̧ma Antalya ilinde faaliyet gösteren otel işletmeleri ile sınırlandırılmıştır. Gelecekte konuyla ilgili farklı illerde ya da farklı sektörlerde çalışmalar yapılabilir. Aynı zamanda otantik liderlik davranışına etki eden farklı unsurlar incelenebilir. Otel işletmeleri yöneticilerine, otantik liderlik davranışı sergilemeleri konusunda eğitim verilerek ve yazılı sözleşmelerin yetersiz kaldığı durumlarda psikolojik sözleşmelerden yararlanılarak, çalışanların işe karşı olan tutum ve davranışları pozitif yönde etkilenebilir.

\section{KAYNAKÇA}

Akbaba, M. (2018). Otel İşletmelerinde Psikolojik Sözleşmenin İşe Yabancılaşma ve Örgütsel Özdeşleşme Üzerine Etkisi, Journal of Institute of Economic Development and Social Researches, 4(9): 320-330.

Akgündüz, Y. (2012). Konaklama İşletmelerinde Otantik Liderlik ve Öz Yeterlilik Arasındaki İlişkinin Analizi, Yayınlanmamış Doktora Tezi, Dokuz Eylül Üniversitesi, İzmir.

Altunışık, R. Coşkun, R. Bayraktaroğlu, S. ve Yıldırım, E. (2005). Sosyal Bilimlerde Araştırma Yöntemleri, (4. Bask1), Sakarya: Sakarya Kitabevi.

Arslan, H. Bader ve Ulaş, D. (2004). İstihdamın Korunması ve İşten Çıkarılanlara Uygulanan Yardımlar. Ege Akademik Bakış Dergisi, 4(2): 102-114. 
Ayça, B. (2016). Otantik Liderlik Davranışının İş Tatmini ve Örgütsel Bağlllığa Etkisinin İncelenmesi ve Otel İşletmelerinde Bir Araştırma, Yayınlanmamış Doktora Tezi, Haliç Üniversitesi, İstanbul.

Aydın, R. (2016). Otel İşletmelerinde Psikolojik Sözleşmeler ve İşgörenlerin İşe Yönelik Tutumları Üzerindeki Etkisi: Antalya 5 Yıldızlı Otel İşletmelerinde Bir Araştırma, Yayınlanmamış Doktora Tezi, Adnan Menderes Üniversitesi, Aydın.

Avcı, N. ve Küçükusta, D. (2009). Konaklama İşletmelerinde Örgütsel Öğrenme, Örgütsel Bağlllık ve İşten Ayrılma Eğilimi Arasındaki İlişki, Anatolia: Turizm Araştırmaları Dergisi, 20(1): 33-44.

Avolio, B. Gardner, W. and Walumbwa, F. L. (2005). Authentic Leadership Theory and Practice: Origins, Effects and Development, Monographs in Leadership and Management, (3): 21-29.

Avolio, B. and Gardner, W. L. (2005). Authentic Leadership Development: Getting to Theroot of Positive Forms of Leadership: The Leadership Quarterly, (16): 315-338.

Cammann, C. Fichman, M. Jenkıns, D. and Klesh, J. (1979). The Michigan Organizational Assessment Questionnaire, Unpublished Manuscript, University of Michigan: Ann Arbor :1-46.

Cinnioğlu, H. ve Saçlı, Ç. (2019). Restoran Çalışanlarının Hizmetkâr Liderlik Algıları ile İşe Adanmışlık Düzeyleri Arasındaki İlişki, İsletme Araştırmaları Dergisi, 11(3): 1769-1778.

Cinnioğlu, H. ve Güler, M. (2020). Restoran İşletmeleri Çalışanlarının Yöneticilerinde Algıladıkları Dönüşümcü Liderlik Davranışının Psikolojik Sermaye ve İş Performansı Düzeyleri Üzerindeki Etkisi: İstanbul Örneği, Erdoğan, T.: Sosyal Bilimlerde Akademik Çalışmalar içinde (ss.:763-786).

Çankaya, M. (2019). Kamu Hastanesi Çalışanlarının Otantik Lidelik Algılarının Sosyodemografik Değişkenler Açısından İncelenmesi, International Social Mentality and Researcher Thinkers Journal 5(24): 1487-1501.

Çiçekoğlu, H. ve Taşlıyan, M. (2018). Psikolojik Sözleşme ve Presenteeism İlişkisi: Bir Alan Araştırması, International Journal of Disciplines Economics \& Administrative Sciences Studies, 4(9): 474-484.

Çolakoğlu, Ü. (2016). Otel İşletmelerinde Psikolojik Sözleşmeler ve İşgörenlerin İşe Yönelik Tutumları Üzerindeki Etkisi: Antalya 5 Yıldızlı Otel İşletmelerinde Bir Araştırma, Yayınlanmamış Doktora Tezi, Adnan Menderes Üniversitesi, Aydın.

Dabos, G. and Rousseau, D. M. (2004). Mutuality and Reciprocity: Psychological Contracts in Research Teams. Journal of Applied Psychology, (89): 52-72.

Dalgıç, A. ve Akgündüz, Y. (2019). Sosyal ve Ekonomik Değişimin Otel Çalışanlarının İşe Adanmışlık ve İşten Ayrılma Niyetine Etkisi, Journal of Tourism Theory and Research, 5(2): 75-85.

Dikili, A. ve Bayraktaroğlu, S. (2013). Psikolojik Sözleşme ile İş Tatmini İlişkisine Yönelik Bir Araştırma, Eskişehir Osmangazi Üniversitesi İIBF Dergisi, 8(2): 205- 227.

Durmuş, B. Yurtkoru, E. S. ve Çinko, M. (2018). Sosyal Bilimlerde SPSS'le Veri Analizi, (7.Basım), İstanbul, Beta Yayıncilık.

Flood, P. C. Ramamoorthy, N. Mcdermott, A. and Conway, E. (2008). Leadership, Human Resource Management and the Content of the Psychological Contract, the Learning, Innovation and Knowledge Research Centre Working Paper Series, WP:03-08. 
Gardner, W. L. Avolio, B. J. Luthans, F. May, D. R. and Walumbwa, F. O. (2005). Can You See the Real Me? A Self-Based Model of Authentic Leader and Follower Development, The Leadership Quarterly, 16(3): 343-372.

Genç Gülertekin, S. ve Gümüş M. (2017). Turizm İşletmelerinde Liderlik Tarzıyla İşten Ayrılma Niyeti İlişkisinde Duygu İkliminin Aracılık Etkisi, Anadolu Üniversitesi Sosyal Bilimler Dergisi, 18(1): 209-228.

Gül, H. İnce, M. ve Candan, H. (2017). Otantik Liderliğin Örgütsel Vatandaşlık Davranışı ve Örgütsel Destek Algısı Üzerindeki Etkisi Üzerine Bir Araştırma, Cag University Journal of Social Sciences, 14(1): 31-53.

https://antalya.ktb.gov.tr/ Erişim Tarihi: 30.04.2020.

Kara, D. Uysal, M. Sirgy, M. J. and Lee, G. (2013). The Effects of Leadership Style on Employee Well-being in Hospitality, International Journal of Hospitality Management, (34): 9-18.

Kesken, J. Ayyıldız, N. A. (2008). Liderlik Yaklaşımlarında Yeni Perspektifler: Pozitif ve Otantik Liderlik, Ege Akademik Bakış Dergisi, 8(2): 729-754.

Kılınç, U. Akdemir, M. (2019). Otel İşletmelerinde Otantik Liderlik Algısı ve İşyeri Mutluluğu: Ankara İlinde Bir Uygulama, Süleyman Demirel Üniversitesi İktisadi ve İdari Bilimler Fakültesi Dergisi 24(4): 793-811.

Ilies, R. Morgeson, F. P. and Nahrgang, J. D. (2005). Authentic Leadership and Eudaemonic WellBeing: Understanding Leader-Follower Outcomes. Leadership Quarterly. 16(3): 373-394

Işkın, Y. ve Kaygın, E. (2016). Otantik Liderlik Anlayışının Örgütsel Bağlılık ve Örgütsel Yabancılaşmayla İlişkisi: Mobilya Sektöründe Bir Araştırma, Bartın Üniversitesi İ.̇.B.F. Dergisi, 7(14): 619-647.

İslamoğlu, A.H. ve Alnıaçık, Ü.B. (2014). Sosyal Bilimlerde Araştırma Yöntemleri, İstanbul, Beta Basım.

Lawer, J. and Ashman L. (2012). Theorizing Leadership Authenticity: A Sartrean Perspective, Leadership, 8(4): 327-344.

Levinson, H. P. Munden C. R. Mandl, K. J. and Solley, C. M. (1962). Men, Management and Mental Health, Boston: Harvard University Press.

Luthans, F. and Avolio, B.J. (2003). Authentic Leadership Development, (Ed) Cameron, K. S. Dutton, J.S. and Quinn, R.: Positive Organizational Scholarship in, San Francisco, BerrettKoehler (pp:241-271).

Meydan, C. H. ve Şeşen, H. (2015). Yapısal Eşitlik Modellemesi Amos Uygulamaları. (2.Basım), Ankara, Detay Yayıncilı.

Millward, L, J. and Hopkins, L. J. (1998). Psychological Contracts, Organizational and Job Commitment, Journal of Applied Social Psychology, (28): 1530-1556.

Millward, L. J. and Brewerton, P. M. (1999). Contractors and Their Psychological Contracts. British Journal of Management, 10, 253-274. 
Mimaroğlu, H. (2008). Psikolojik Sözleşmenin Personelin Tutum ve Davranışlarına Etkileri: Tıbbi Satış Temsilcileri Üzerinde Bir Araştırma, Yayımlanmamış Doktora Tezi, Çukurova Üniversitesi, Adana.

Nam, S. (2018). Psikolojik Sözleşme ve İş Tatmini İlişkisi Üzerine Bir Araştırma, International European Journal of Managerial Research, 2(3): 43-60.

Nikpay, I. Siadat, S. Hoveida, R. and Nilfrooshan, P. (2014). Developing a Model for Effect of Perception of Authentic Leadership on Individual Oriented and Organizational Oriented Organizational Citizenship Behaviors at Universities, Educational Research International, 3(2): 6473.

Okşit, Ç. ve Kılıç, G. (2019). Hizmetiçi Eğitimin Örgütsel Özdeşleşme ve İşten Ayrılma Niyetine Etkisi: Antalya'daki Beş Yıldızlı Otel İşletmeleri Örneği, Journal of Tourism and Gastronomy Studies, 7(1): 46-70.

Özdaşlı, K. ve Çelikkol, Ö. (2012). Psikolojik Sözleşme: Kavramsal Çerçeve ve Bir İçerik Analizi, Mehmet Akif Ersoy Üniversitesi Sosyal Bilimler Enstitüsü Dergisi, 4(7): 141-154.

Özdemir, H. Ö. (2017). Yöneticilerin Otantik Liderlik Tarzlarının Çalışanların Sanal Kaytarma ve Sinizm Davranışları Üzerine Etkileri, Yayımlanmamış Doktora Tezi, Nevşehir Hacı Bektaş Veli Üniversitesi, Nevşehir.

Özgen, M. H. ve Özgen, H. (2010). Psikolojik Sözleşme ve Boyutlarının İş Tatmini, Örgütsel Bağlılık ve İşten Ayrılma Niyetine Etkileri: Tıbbi Satış Temsilcileri Üzerinde Bir Araştırma, Ç.Ü Sosyal Bilimler Enstitüsü Dergisi, 19(1): 1-19.

Robinson, S. L. (1996). Trust and Breach of the Psychological Contract, Administrative Science Quarterly, 41(4): 574-599.

Rousseau, D.M. (1990). New Hire Perceptions of Their Own and Their Employer's Obligations: A Study of Psychological Contracts, Journal of Organizational Behavior, 11, 389-400.

Rousseau, D. M. and Tijoriwala, S. A. (1998). Assessing Psychological Contracts: Issues, Alternatives and Measures, Journal of Organizational Behavior, (19): 679-695.

Rousseau, D. M. (2000). Psychological Contract Inventory Technical Report :1-30. http://www.andrew.cmu.edu/user/rousseau/0_reports/PCI.pdf (Erişim Tarihi: 02.04.2020).

Rusblt, C., Rogers, G. and Arch, G. M. (1988). Impact of Exchange Variables on Exit, Voice, Loyalty and Neglect: An Integrative Model of Responses to Decline Job Satisfaction, Academy of Management Journal, 31(3): 599-627

Salha, H., Cinnioğlu, H. ve Yazıt, H. (2016). Psikolojik Sözleşme İhlal Algısının Tükenmişlik Üzerine Etkisi: Yiyecek İçecek İşletmeleri Üzerine Bir Araştırma, 17. Ulusal Turizm Kongresi, Muğla.

Susskind, A. M. Borchgrevınk, C. P; Kacmar, K. M. and Brymer, R. A. (2000). Customer Service Employees"e Behavioral Intentions and Attitudes: An Examination of Construct Validity and A Path Model, International Journal of Hospitality Management,19(1): 53-77.

Subramanian, I. D. and Shin, Y. N. (2013). Perceived Organizational Climate and Turnover Intention of Employees in the Hotel Industry, World Applied Sciences Journal, 22(12): 1751-1759 
Sökmen, A. ve Sezgin Ceyhun, A. (2017). İş Tatmini ve İşten Ayrılma Niyetinin Değerlendirilmesi: Otel İşletmeleri Sınır Birim Çalışanları Üzerine Bir Araştırma, Journal of Tourism and Gastronomy Studies, 5(2): 237-250.

Tabak, A. Polat, M. Coşar, S. ve Türköz, T. (2012). Otantik Liderlik Ölçeği: Güvenilirlik ve Geçerlilik Çalışması, İ̧̧ Güç Endüstri İlişkileri ve İnsan Kaynakları Dergisi, 14(4): 89-106

Tanrıverdi, H. Akkova, O. ve Çiftçi, İ. (2016). Açılış-Otellerinde Dönüşümcü, Etkileyici, Tam Serbesti Tanıyan Liderlik Tarzlarının ve Çatışma Yönetim Stillerinin İşten Ayrılma Niyeti Üzerine Etkisi, KMÜ Sosyal ve Ekonomik Araştırmalar Dergisi, 18(30): 114 - 123

Tanrıverdi, H., Koçaslan, G. ve Taştan, N. (2018). Psikolojik Şiddet Algısı, Tükenmişlik Sendromu ve İşten Ayrılma Niyeti Arasındaki İlişki: Banka Çalışanları Üzerinde Bir Araştırma, Yönetim ve Ekonomi Dergisi, 25(1):113-131.

Taşlıyan, M. Hırlak, B. (2016). Otantik Liderlik, Psikolojik Sermaye, İşten Ayrılma Niyeti ve Çalışan Performansı Arasındaki İlişki: Hemşireler Üzerinde Bir Araştırma, Uluslararası Hakemli Sosyal Bilimler E-Dergisi, (56): 92-115.

Tett, R. P, and Meyer, J. P (1993). Job Satisfaction, Organizational Commitment, Turnover Intention, and Turnover: Path Analyses Based on Meta-Analytic Findings, Personnel Psychology, (47): 259-293.

Turhan, M. (2007). Genel ve Mesleki Lise Yöneticilerinin Etik Liderlik Davranışlarının Okullardaki Sosyal Adalet Üzerindeki Etkisi, Yayımlanmamış Doktora Tezi, Fırat Üniversitesi, Sosyal Bilimler Enstitüsü

Türk, M. ve Akbaba, M. (2017). Turizm İşletmelerinde Yetenek Yönetimi Algılamalarının Örgütsel Uyum ve İşten Ayrılma Niyeti Üzerine Etkisi, The Journal of Academic Social Science Studies, 62, 465-479

Türk, M. ve Akbaba, M. (2018). Etik Liderlik Algısının Psikolojik Kontrat İhlali ve Örgütsel Özdeşleşme Üzerine Etkisi: Antalya ilindeki Beş Yıldızlı Konaklama İşletmeleri Üzerine Bir Araştırma, Türk \& İslam Dünyası Sosyal Araştırmalar Dergisi, 5(16): 382-407.

Walumbwa F. O. Avolio B. J. Gardner W. L. Wernsing T. S. and Peterson S. J. (2008). Authentic Leadership: Development and Validation of a Theory-Based Measure, Journal of Management, 34(1): 86-126.

Walumbwa, F. O. Wang, P. Wang, H. Schaubroeck J. and Avolio B. J. (2010). Psychological Processes Linking Authentic Leadership to Follower Behaviors, The Leadership Quarterly, (21): 901-914. 